\title{
Akut pankreatitli hastalarda akut böbrek hasarını öngörmedeki nötrofil lenfosit oranının rolü
}

\author{
The role of the neutrophil-to-lymphocyte ratio in predicting acute kidney injury in patients with \\ acute pancreatitis
}

Zeynep BIYIK
Selçuk Üniversitesi Tıp Fakültesi, Nefroloji Bilim Dalı, Selçuklu, Konya

Giriş ve Amaç: Bir inflamasyon belirteci olan nötrofil lenfosit oranının çeşitli hastalıklarda akut böbrek hasarı gelişimini predikte ettiği gösterilmiştir. Biz de akut pankreatitte akut böbrek hasarını predikte etmede nötrofil lenfosit oranının rolünü araştırmayı amaçladık. Gereç ve Yöntem: Bu retrospektif çalışmaya Eylül 2016 ve Eylül 2018 yılları arasında Selçuk Üniversitesi Tıp Fakültesi'nde akut pankreatit tanısı ile takip edilen 186 hasta dahil edildi. Akut pankreatit tanısı ve şiddetinin belirlenmesinde Atlanta sınıflaması kullanıldı. Hastaların acile ilk başvuru sırasındaki laboratuvar değerleri ve prognostik skorlama sistemleri kullanıldı. Akut böbrek hasarı tanısı ve evrelemesi için KDIGO kriterleri kullanıldı. Bulgular: Çalı̧̧maya alınan 186 hastanın yaş ortalaması $59.3 \pm 17.3$ olup \%59.7'si kadındı. Hastaların \%26.3'ünde akut böbrek hasarı gelişmişti. Akut böbrek hasarı gelişen hastalar akut böbrek hasarı gelişmeyen hastalarla karşılaştıııldığında daha ileri yaşta oldukları ve hipertansiyon sıklığının daha fazla olduğu görüldü (her ikisi için $p<0.001$ ). Akut böbrek hasarı gelişen hastaların yatış süreleri ve yoğun bakım yatış süreleri anlamlı olarak uzun bulundu (her ikisi için $p=0.001$ ). Akut böbrek hasarı grubunda beyaz küre ve nötrofil sayıları anlamlı olarak yüksek bulunurken lenfosit sayısı anlamlı olarak düşü̈k bulundu (her üçü için de $p$ <0.001). Hastaneye kabulde bakılan nötrofil lenfosit oranı ve C-reaktif protein de akut böbrek hasarı grubunda anlamlı olarak daha yüksekti (her ikisi için $p<0.001)$. Hematokrit, trombosit ve kırmızı kan hücreleri dağılım genişliği değerleri her iki grupta benzerdi ( $p>0.05)$. Akut pankreatit hastalarında akut böbrek hasarı gelişimini bağımsız olarak predikte eden faktörleri belirlemek için yapılan multivariate regresyon analizinde yaş (OR: 0.964, \%95 Cl: 0.925-1.004, p: 0.008), nötrofil lenfosit oranı (OR: $1.096, \% 95 \mathrm{Cl}: 1.028-1.170, p: 0.005)$ ve BISAP skoru (OR: 6.582, \%95 Cl: 2.810-15.414, p <0.001) bağımsız etkili faktörler olarak belirlendi. Akut böbrek hasarını öngörmede nötrofil lenfosit oranının ROC eğrisinin altında kalan alan (area under curve) 0.813 (\%95 Cl 0.742-0.883), 11.24 kesme değeri için duyarlılık \%73.4 ve özgüllük ise \%81.4 olarak tespit edildi. Sonuç: Hastaneye kabulde bakılan nötrofil lenfosit oranı akut pankreatitli hastalarda akut böbrek hasarı gelişimini predikte etmede faydalı bir belirteç olabilir.

Anahtar kelimeler: Akut pankreatit, nötrofil lenfosit oranı, akut böbrek hasarı

Background and Aims: Neutrophil-to-lymphocyte ratio is an inflammatory marker that has been demonstrated to predict the development of acute kidney injury in various diseases. We investigated the role of the neutrophil-to-lymphocyte ratio in predicting acute kidney injury in patients with acute pancreatitis. Materials and Method: A total of 186 patients diagnosed with acute pancreatitis in Selcuk University School of Medicine between September 2016 and September 2018 were included in this retrospective study. The diagnosis and severity of acute pancreatitis were defined according to the revised Atlanta classification, while the KDIGO criteria were used for the diagnosis and staging of acute kidney injury. We also collected details pertaining to laboratory values and prognostic scoring systems of the patients obtained at their first visit to the emergency service. Results: Of the 186 patients, more than half were females (59.7\%), and the average age of the patients was $59.3 \pm 17.3$ years. Acute kidney injury was detected in $26.3 \%$ of the patients, who were found to be older and more hypertensive than patients without acute kidney injury ( $p=0.001$ for both). The duration of hospitalization and the duration of intensive care unit stay of patients with acute kidney injury were significantly longer ( $p=0.001$ for both). White blood cell and neutrophil counts were significantly higher in the acute kidney injury group, whereas the lymphocyte count was significantly lower ( $p<0.001$ for all three). The neutrophil-to-lymphocyte ratio and C-reactive protein levels measured during patient admission were significantly higher in the acute kidney injury group ( $p<0.001$ for both). Hematocrit, thrombocyte, and red cell distribution width values were similar in both groups $(p>0.05)$. The multivariate regression analysis showed that age (OR: $0.964,95 \% \mathrm{Cl}: 0.925-1.004, p=0.008$ ), neutrophil-to-lymphocyte ratio (OR: 1.096, 95\% Cl: 1.028-1.170, $p=0.005)$, and BISAP score (OR: 6.582, 95\% Cl: 2.810-15.414, $p<0.001$ ) were independent predictors of acute kidney injury for determining the factors that could independently predict the development of acute kidney injury in patients with acute pancreatitis. The receiver operating characteristic curve revealed an area under curve of 0.813 (95\% Cl: $0.742-0.883$ ), a sensitivity of $73.4 \%$, and a specificity of $81.4 \%$ for a cut-off neutrophil-to-lymphocyte ratio value of 11.2. Conclusions: Baseline neutrophil-to-lymphocyte ratio evaluated during patient admission may be a useful predictor of acute kidney injury in patients with acute pancreatitis.

Key words: Acute pancreatitis, acute kidney injury, neutrophil-to-lymphocyte ratio

\footnotetext{
iletişim: Zeynep BIYIK

Selçuk Üniversitesi Tıp Fakültesi, Nefroloji Bilim Dalı, Selçuklu/Konya/Türkiye Tel: +90 3322415000 • Faks: +90 3322412184 E-mail: drzeynepbiyik@gmail.com
}

Biylk Z. The role of the neutrophil-to-lymphocyte ratio in predicting acute kidney injury in patients with acute pancreatitis. The Turkish Journal of Academic Gastroenterology 2019;18:16-22. DOl: 10.17941/agd.548747

Geliş Tarihi: 30.11.2018 • Kabul Tarihi: 31.12.2018 


\section{GíRiş}

Akut pankreatit pankreasın akut inflamatuvar bir durumudur. Hafif akut pankreatitten çevre doku veya uzak organları tutabilen şiddetli akut pankreatite kadar geniş bir spektrumda görülebilir. Akut pankreatitte asiner hücre hasarı lokal inflamatuvar reaksiyona yol açmaktadır. Sitokin kaskadının aktivasyonu ise sistemik inflamasyona neden olmaktadır (1).

Akut böbrek hasarı $(\mathrm{ABH})$ akut pankreatitli hastaların yaklaşık \%15'inde görülür $(2,3)$. Şiddetli akut pankreatitte ise \%69 gibi yüksek oranlarda akut böbrek hasarı geliştiği bildirilmiştir (4). Akut pankreatitli hastalarda akut böbrek hasarı gelişimi hem mortaliteyi hem morbiditeyi hem de tedavi maliyetlerini artırmaktadır (3). Şiddetli akut pankreatitte $A B H$ gelişmesi durumunda mortalitede 10 kat artış bildirilmiştir (5). Dolayısıyla ABH'nın erken tanınması ve önlenmesi önem arz etmektedir.

Akut pankreatitli hastalarda $\mathrm{ABH}$ gelişiminin prediktörleri iyi tanımlanmamıştır. Kreatinin böbrek hasarı tespitinde en sık kullanılan belirteç olması rağmen $\mathrm{ABH}$ erken tanısında sensitivitesi düşüktür. Bazı biyobelirteçler serum kreatininden daha erken yükseldiği için $\mathrm{ABH}$ tanısında yardımcı olurlar. Ancak bunlar da pahalıdır ve rutin kullanımda değildirler (10). Bu nedenle akut böbrek hasarını erken predikte edecek daha sensitif ve pratikte kullanıma uygun belirteç arayışları devam etmektedir.

$\mathrm{ABH}$ patofizyolojisinde inflamasyonun rolü giderek daha fazla tanımlanmaktadır $(6,7)$. Nötrofil lenfosit oranı (NLO) da kolay hesaplanabilen, ucuz ve sensitif olan, sistemik inflamasyonu yansıtan bir parametredir (8). Akut pankreatitin şiddetini (1) ve mortaliteyi predikte ettiği gösterilmiş olan önemli bir belirteçtir (9). Sepsisli hastalarda, sirotik hastalarda ve acile başvuran hastalarda akut böbrek hasarını predikte etmede nötrofil lenfosit oranının rolü gösterilmiştir (10-12). Biz de akut pankreatitli hastalarda akut böbrek hasarı gelişimini predikte etmede NLO'nın rolünü araştırmayı amaçladık.

\section{GEREÇ ve YÖNTEM}

Bu retrospektif çalışmaya Selçuk Üniversitesi Tıp Fakültesi'nde Ekim 2016 ve Ekim 2018 arasında akut pankreatit tanısı ile izlenen 186 hasta dahil edildi. Çalışmaya 18 yaş üstü hastalar alındı. Malignite, hemodiyaliz veya periton diyalizi hastaları, gebelik, steroid kullanımı, karaciğer yetmezliği, 48 saatten daha kısa yatış süresi ve veri eksikliği dışlama kriterleri olarak kabul edildi. Rekürren pankreatitle yatan hastaların sadece ilk yatışları dahil edildi. Hastaların yaş, cinsiyet, komorbidite, etiyoloji, komplikasyon, hemodiyaliz ve mortalite bilgileri medikal kayıtlarından elde edildi. Tedavi öncesi acile ilk başvuruda bakılan hemogram, C-reaktif protein (CRP), üre, kreatinin, albümin, kalsiyum, aspartat aminotransferaz (AST), alanin aminotransferaz $(A L T)$, laktat dehidrogenaz $(L D H)$, amilaz, lipaz kaydedildi. ABH tanısı için yatış boyunca bakılan kreatinin değerleri de kaydedildi.

Şu üç kriterden ikisinin varlığı akut pankreatit olarak tanımlandı (13). 1) Karın ağrısı (Karakteristik olarak ani başlayan, şiddetli, sürekli sıklıkla sırta vuran epigastrik ağrı), 2) Normalin üst sınıının 3 kat ve daha üzeri serum amilaZı ve/veya lipazı 3) Bilgisayarlı tomografi (BT), magnetik rezonans (MR) veya abdominal ultrasonografide karakteristik akut pankreatit bulguları.

Akut pankreatit şiddeti klinik değerlendirmeye göre sınıflandırıldı. Bunun için revize edilmiş Atlanta sınıflandırması kullanıldı. Hafif akut pankreatit organ yetmezliği ve lokal/sistemik komplikasyon olmaması olarak tanımlandı. Orta şiddetli akut pankreatit 48 saat içinde düzelen geçici organ yetmezliği ve/veya kalıcı organ yetmezliğinin eşlik etmediği lokal veya sistemik komplikasyonlar olarak tanımlandı. Şiddetli akut pankreatit ise bir veya birden fazla organın tutulduğu kalıcı organ yetmezliği olarak kabul edildi. Akut peripankreatik sıvı koleksiyonları, pankreatik psödokist, akut nekrotik koleksiyon ve organize nekroz akut pankreatit şiddetini belirlemede kullanılan lokal komplikasyonlardı (13).

Akut böbrek hasarı KDIGO kriterlerine göre tanımlandı. 48 saat içinde serum kreatininde $\geq 0,3 \mathrm{mg} / \mathrm{dL}$ artış olması veya son 7 gün içinde ortaya çıktığı bilinen ya da tahmin edilen serum kreatinin düzeyinde başlangıca göre $\geq 1,5$ kat artış ABH olarak tanımlandı (14). İdrar kriterleri kullanılmadı. Akut böbrek hasarı evrelemesinde de KDIGO kriterleri kullanıldı. Bazal kreatinin değerinden 1.5-1.9 kat kreatinin artışı veya $\geq 0.3 \mathrm{mg} / \mathrm{dl}$ artış evre $1 \mathrm{ABH}$ olarak, bazal kreatinin değerinden 2-2.9 kat artış evre $2 \mathrm{ABH}$ olarak, bazal kreatinin değerinden 3 kat artış ya da serum kreatinin $>4.0 \mathrm{mg} / \mathrm{dl}$ ya da renal replasman tedavisi başlanması evre $3 \mathrm{ABH}$ olarak değerlendirildi. Hastaların yatış süresi boyunca bakılan tüm kreatinin değerleri değerlendirmeye alındı.

Laboratuvarda hematoloji otoanalizörü olarak Beckman Coulter LH 780 kullanıldı. Nötrofil lenfosit oranı mutlak nötrofil sayısının mutlak lenfosit sayısına bölünmesi ile elde edildi.

\section{İstatistiksel Analiz}

Normal dağılımı test etmek için Kolmogorov- Smirnov testi kullanıldı. Sürekli değişkenler ortalama \pm standart sapma, normal dağılmayan sürekli değişkenler ortanca 
(minimum-maksimum) ve kategorik veriler de yüzde olarak gösterildi. Grupların karşılaştırıldığı analizlerde kategorik değişkenler için ki-kare, sürekli değişkenler için t-testi ve normal dağılmayan verilerde Mann Whitney U-testi yapıldı. ABH gelişimi için bağımsız etkili faktörleri göstermek için Backward Multivariate Regresyon analizi yapıldı. Ayrıca ABH predikte etmede NLO'nın duyarlılık ve özgüllüğünü tespit etmek için ROC (Receiver Operating Characteristic Curve) eğrisi ve eğri altında kalan alan (AUC) hesaplaması kullanıldı ve optimal kesme değeri belirlendi. p değeri $0.05^{\prime}$ in altı anlamlı olarak kabul edildi. İstatistiksel analizler için SPSS 22 (IBM Corp, SPSS, NY, USA) programı kullanıldı.

\section{BULGULAR}

Çalışmaya 186 hasta dahil edildi. Çalışmaya alınan hastaların yaş ortalaması 59.3 \pm 17.3 ve 111 hasta (\%59.7) kadındı. Akut pankreatitin en sık sebebi \%78 ile safra taşı idi. Akut böbrek hasarı gelişen ve gelişmeyen hasta gruplarının klinik ve demografik özellikleri Tablo 1'de, laboratuvar özellikleri Tablo 2'de gösterilmiştir.
Hastane yatışı süresince 49 (\%26.3) hastada ABH tespit edildi. ABH gelişen hastalar daha ileri yaşta idi (66.8 \pm 12.6

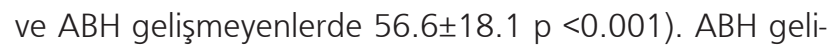
şen hastalarda yatış süreleri ve yoğun bakım yatış süreleri $\mathrm{ABH}$ gelişmeyen hastalarla karşılaştırıldığında anlamlı olarak uzun bulundu (her ikisi için $p=0.001$ ). Hipertansiyon $\mathrm{ABH}$ gelişen grupta anlamlı olarak daha sık görülmekte iken ( $p<0.001)$ diyabetes mellitus açısından her iki grup benzerdi ( $p=0.258$ ). Beklendiği gibi Ranson skoru ve BISAP skoru $A B H$ gelişen grupta anlamlı olarak daha yüksekti (her ikisi için $p<0.001$ ). Atlanta sınıflandırmasına göre değerlendirildiğinde akut böbrek hasarı şiddetli (\%24.5) ve orta şiddetli (\%75.5) akut pankreatitte görüldü.

$\mathrm{ABH}$ gelişen ve gelişmeyen grup arasında amilaz ve lipaz değerleri açısından anlamlı fark yoktu (her ikisi için $p>0.05)$. AST $(p=0.043), \operatorname{ALT}(p=0.040), \operatorname{LDH}(p=0.002)$, ve glukoz değerleri ( $p=0.027) \mathrm{ABH}$ gelişen grupta anlamIı yüksek tespit edilirken, albümin $(p=0.026)$ ve kalsiyum değerleri $(p=0.001)$ bu grupta anlamlı olarak düşük bulundu.

Tablo 1. Çalışma hastalarının klinik ve demografik özellikleri

\begin{tabular}{|c|c|c|c|}
\hline & $\mathrm{ABH}(+)$ & $A B H(-)$ & $p$ \\
\hline$n,(\%)$ & $49(26.3)$ & $137(73.7)$ & \\
\hline Yaş, yıl & $66.8 \pm 12.6$ & $56.6 \pm 18.1$ & $<0.001$ \\
\hline Cinsiyet (erkek) & $22(44.9)$ & $53(38.7)$ & 0.276 \\
\hline \multicolumn{4}{|l|}{ Etiyoloji, n (\%) } \\
\hline Safta taşları & $42(97.7)$ & $103(94.5)$ & 0.803 \\
\hline Hiperlipidemi & $1(2.3)$ & $4(3.7)$ & \\
\hline Alkol & 0 & $1(0.9)$ & \\
\hline Otoimmün & 0 & $1(0.9)$ & \\
\hline Nedeni bilinmeyen & $6(12.2)$ & $28(27.7)$ & \\
\hline Yatış süresi, gün & $6(2-24)$ & $5(2-16)$ & 0.001 \\
\hline Yoğun bakım yatış süresi & $2(0-11)$ & $0(0-8)$ & 0.001 \\
\hline Hemodiyaliz ihtiyacı & 5 & 0 & $<0.001$ \\
\hline Diyabetes mellitus, n (\%) & $14(28.6)$ & $31(22.6)$ & 0.258 \\
\hline Hipertansiyon, n (\%) & $28(57.1)$ & $34(24.8)$ & $<0.001$ \\
\hline Mortalite, & 7 & 0 & $<0.001$ \\
\hline \multicolumn{4}{|l|}{ Prognostik skorlar } \\
\hline Ranson skoru & $5(2-8)$ & $2(0-6)$ & $<0.001$ \\
\hline BISAP skoru & $2(1-5)$ & $1(0-3)$ & $<0.001$ \\
\hline Atlanta sınıflandırması & & & $<0.001$ \\
\hline Hafif & $4(\% 8.2)$ & $84(\% 61.3)$ & \\
\hline Orta & $33(67.3)$ & $53(38.7)$ & \\
\hline Ağır & $12(\% 24.5)$ & $0(\% 0)$ & \\
\hline
\end{tabular}


Tablo 2. Çalışma hastalarının laboratuvar özellikleri

\begin{tabular}{|c|c|c|c|}
\hline & ABH $(+)$ & ABH $(-)$ & $p$ \\
\hline Üre, mg/dl & $50(22-136)$ & $30(14-98)$ & $<0.001$ \\
\hline Kreatinin, mg/dl & $1.22(0.57-3.69)$ & $0.74(0.34-1.1)$ & $<0.001$ \\
\hline Glukoz, mg/dl & $131(58-154)$ & $122(46-433)$ & 0.027 \\
\hline Kalsiyum, mg/dl & $8.35 \pm 0.92$ & $8.74 \pm 0.63$ & 0.001 \\
\hline Albumin, $\mathrm{g} / \mathrm{dL}$ & $3.12 \pm 0.71$ & $3.56 \pm 0.66$ & 0.026 \\
\hline AST, U/L & $174(21-1330)$ & $127(12-1700)$ & 0.043 \\
\hline ALT, U/L & $185(22-1386)$ & $114(7-1101)$ & 0.040 \\
\hline LDH, U/L & 368 (189-1789) & $296(142-1661)$ & 0.002 \\
\hline Amilaz, U/L & $1437(137-6701)$ & $1128(141-5534)$ & 0.151 \\
\hline Lipaz, U/L & $2657(131-20990)$ & $1948(155-18896)$ & 0.213 \\
\hline CRP, mg/dl & $12.8(1.19-46.6)$ & $2.25(0.15-49.7)$ & $<0.001$ \\
\hline Lökosit, $\times 10^{9} / \mathrm{L}$ & $14(7.2-29.9)$ & $10.9(4-24.8)$ & $<0.001$ \\
\hline Nötrofil, $\times 10^{9} / \mathrm{L}$ & $11.6(6-27.2)$ & $8.59(2.5-22.5)$ & $<0.001$ \\
\hline Lenfosit, $\times 10^{9} / \mathrm{L}$ & $0.87(0.2-3.32)$ & $1.56(0.17-5.16)$ & $<0.001$ \\
\hline Nötrofil lenfosit oranı & $16.8(2.67-51)$ & $5.29(1.28-38.9)$ & $<0.001$ \\
\hline Hematokrit, (\%) & $42.7 \pm 5.66$ & $40.9 \pm 5.68$ & 0.061 \\
\hline RDW, (\%) & $14.4(12.4-22.3)$ & $13.9(12.2-18.9)$ & 0.129 \\
\hline Trombosit, $\times 10^{9} / \mathrm{L}$ & $247 \pm 91.9$ & $249.4 \pm 79.6$ & 0.861 \\
\hline Monosit, $\times 10^{9} / \mathrm{L}$ & $0.7(0.008-4.63)$ & $0.57(0.001-4.34)$ & 0.432 \\
\hline
\end{tabular}

AST: Aspartat aminotransferaz, ALT: Alanin aminotransferaz, LDH: Laktat dehidrogenaz, CRP: C-reaktif protein, RDW: Kırmızı kan hücresi dağııım genişliği.

Tablo 3. Akut pankreatitli hastalarda ABH gelişimini predikte eden faktörler için multivariate regresyon analizi

\begin{tabular}{|lcccc}
\hline Değişken & $\beta$ & OR & Güven Aralığı & p \\
\hline Yaş & -0.037 & 0.964 & $0.925-1.004$ & 0.008 \\
\hline NLO & 0.092 & 1.096 & $1.028-1.170$ & 0.005 \\
\hline BISAP skoru & 1.884 & 6.582 & $2.810-15.414$ & $<0.001$ \\
\hline
\end{tabular}

NLO: Nötrofil lenfosit oranı, BISAP: Bedside Index of Severity In Acute Pancreatitis, OR: Odds Ratio

Hemogram parametrelerine bakıldığında $\mathrm{ABH}$ grubunda lökosit ve nötrofil sayıları anlamlı olarak yüksek bulunurken, lenfosit sayısı anlamlı olarak düşük bulundu (her üçü için de $p$ <0.001). Hastaneye kabulde bakılan NLO da $\mathrm{ABH}$ grubunda [median değer $\mathrm{ABH}(+)$ grupta 16.8, $\mathrm{ABH}$ (-) grupta 5.29] anlamlı olarak daha yüksekti $(p<0.001)$. Hematokrit, trombosit ve kırmııı kan hücreleri dağılım genişliği (RDW) değerleri her iki grupta benzerdi ( $p>0.05$ ). Diğer bir inflamasyon belirteci olan CRP ise ABH grubunda anlamlı olarak daha yüksek bulundu ( $p<0.001)$. NLO ile Ranson skoru arasında anlamlı olarak korelasyon bu- lundu ( $r=0.551, p<0.001)$. Benzer şekilde NLO ve BISAP skoru da pozitif korele idi $(r=0.475, p<0.001)$.

Akut pankreatitle takip edilen ve $\mathrm{ABH}$ gelişen hastaların çoğunda (\%65.3) evre $1 \mathrm{ABH}$ tespit edildi. Evre $2 \mathrm{ABH} A B \mathrm{BH}$ gelişen hastaların \%16.3'ünde, evre $3 \mathrm{ABH}$ ise $\% 18.4^{\prime}$ ünde görüldü. Hemodiyaliz intiyacı 5 hastada ortaya çıkı. Bu hastaların tamamı evre $3 \mathrm{ABH}$ grubundaydı. Yatış süresince 7 hasta mortal seyretti ve bunların tamamı $\mathrm{ABH}$ gelişen grupta idi. Evrelere göre mortaliteye bakıldığında ise evre $1 \mathrm{ABH}$ grubunda 3 hasta, evre $2 \mathrm{ABH}$ grubunda 1 hasta ve evre $3 \mathrm{ABH}$ grubunda 3 hasta mortalite ile sonuçlandı. 
Akut pankreatit hastalarında $\mathrm{ABH}$ gelişimini bağımsız olarak predikte eden faktörleri belirlemek için yapılan multivariate regresyon analizinde yaş (OR=0.964 GA 0.925-1004 $p=0.008)$, NLO (OR=1.096 GA 1.028-1.170 $p=0.005)$ ve BISAP skoru (OR=6.582 GA 2.810-15.414 $\mathrm{p}<0.001)$ bağımsız prediktörler olarak belirlendi (Tablo 3).

ABH'ı predikte etmede NLO'nın ROC eğrisinin altında kaIan alan (AUC-Area Under Curve) 0.813 (\%95 GA 0.7420.883), 11.24 kesme değeri için duyarlılık \%73.4 ve özgüllük ise \%81.4 olarak tespit edildi (Şekil 1).

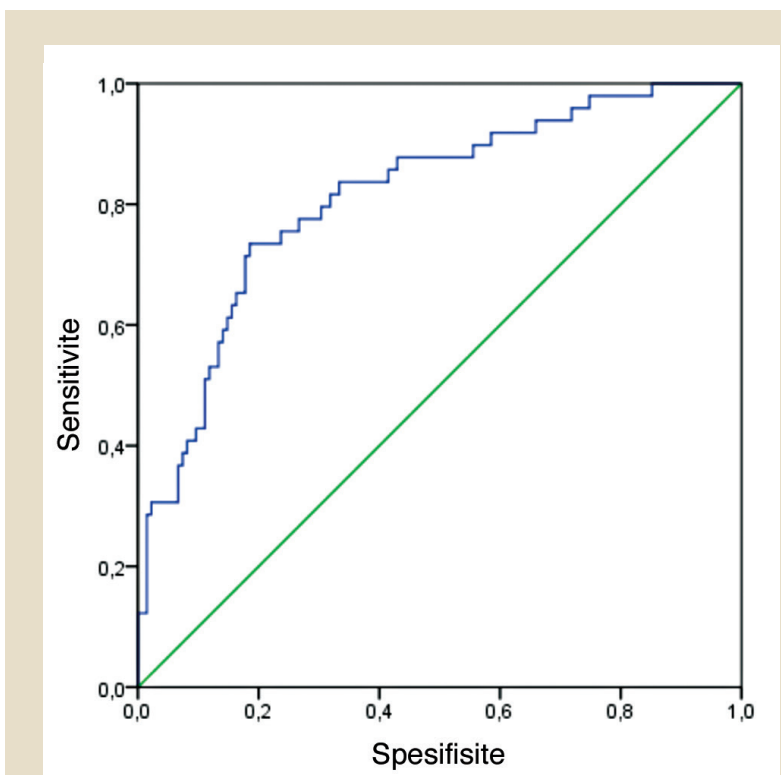

Şekil 1. Akut pankreatitli hastalarda akut böbrek hasarı prediktörü olarak nötrofil lenfosit oranı için ROC eğrisi

\section{TARTIŞMA}

Bu çalışmanın ana bulgusu akut pankreatitli hastalarda akut böbrek hasarı gelişiminde nötrofil lenfosit oranının potansiyel bir noninvaziv belirteç olarak tespit edilmesidir. Çalışmamızda ABH gelişmeyen hastalarla karşılaştırıdığında ABH gelişen hastalarda NLO anlamlı olarak daha yüksekti. Kesme değeri 11.24, akut böbrek hasarı gelişimini \%73.4 duyarlılık ve \%81.4 özgüllük ( $A \cup C=0.813$ \%95 GA 0.742-0.883) ile öngördürmüştür.

Son yıllarda $\mathrm{ABH}$ patofizyolojisinde NLO'nın rolü ile ilgili çok sayıda deneysel ve klinik çalışma yapılmıştır $(6,7,15)$. Lokal olarak vasküler endotel hücresi, tübül epitel hücresi ve lökositlerde iskemi veya reperfüzyonla başlayan değişiklikler böbrekte immün dengenin kaybı ile sonuçlanır. Bunu takip eden inflamasyon böbrek parankim hücresi ölümüne yol açar ve şiddetli olan vakalarda akut böbrek hasarı gelişir (16). Ayrıca ABH da inflamatuvar mediatörlerin metabolizmasının bozulması, renal üretim artışı veya renal klirenste azalma nedeniyle nonspesifik sistemik inflamasyona yol açabilir (17).

$A B H^{\prime}$ da nötrofil ve lenfositlerin etkisi araştırılmıştır. Postiskemik böbrekte gelişen iskemi reperfüzyon hasarında nötrofil birikimi karakteristiktir $(18,19)$. Nötrofil azalması ise $A B H^{\prime}$ ı önlemektedir (20). $A B H^{\prime}$ da lenfositlerin rolüne bakıldığında ise $A B H^{\prime}$ nın hem erken hem de geç fazında T lenfosit infiltrasyonu ile karakterize olduğu görülür. Bu hasarı kolaylaştırabileceği gibi iskemi hasarı sonrası tamiri de uyarır (21).

NLO ümit verici bir inflamatuvar belirteçtir. Sistemik inflamasyonla nötrofili ve lenfopeni arasındaki fizyolojik ilişki ilk defa Zahorek ve arkadaşları tarafından tanımlanmıştır (22). NLO inflamatuvar hasara hasta yanıtının göstergesi olabilir. Hasara yanıtta nötrofiller artar, çok kuvvetli yanıt olduğunda ise lenfosit apopitozu ve redistribüsyonu indüklenir (23). Böylece NLO artar.

Akut pankreatitli hastalarda NLO'nın kötü sonuçlarla ilişkisini gösteren çalışmalar yayınlanmıştır. Li ve arkadaşları 359 hastayı retrospektif olarak değerlendirmişler ve NLO'nın şiddetli akut pankreatiti ve mortaliteyi bağımsız olarak predikte ettiğini göstermişlerdir (9). NLO'nın mortaliteyi predikte etmedeki kesme değeri bu çalışmada 16.64 bulunmuştur.

Azab ve arkadaşları 283 akut pankreatitli hasta ile yaptıkları çalışmada akut pankreatitin kötü sonuçlarını (uzun yatış süresi ve yoğun bakım yatışı) predikte etmede NLO'ı toplam lökosit sayısına göre üstün bulmuşlar ve NLO 4.7'nin üzerini pankreatit şiddetinin göstergesi olarak bildirmişlerdir. Ancak bu çalışmada $A B H$ değerlendirilmemiştir (24).

Jeon ve arkadaşları tarafından ise NLO hem şiddetli akut pankreatitle hem de organ yetmezliği ile ilişkili bulunmuştur. Bu çalışmada organ yetmezliği şok, pulmoner yetmezlik ve renal yetmezlik olarak tanımlanmış. Ancak bu çalışmada renal yetmezlik tanımı hidrasyon sonrası serum kreatinin seviyelerinin $2 \mathrm{mg} / \mathrm{dl}$ veya üzerinde olması veya hemodiyaliz ihtiyacı olması şeklinde kabul edilmiştir. Yani hafif akut böbrek hasarı olan hastalar renal yetmezlik olarak tanımlanmamıştır. Bu çalışmada da Azap ve arkadaşlarına benzer şekilde NLO 4.76 üzerinin şiddetli akut pankreatiti predikte ettiği belirlenmiştir (25).

Sadece hipertrigliseridemiye bağlı akut pankreatitli 110 hastanın değerlendirildiği bir çalışmada NLR 10'un üzerinde olan hastalarda ABH görülme oranı \%25.9 iken NLO 10'un altında bu oran \%3.6 bulunmuştur. Bu çalışmada $\mathrm{ABH}$ tanımı serum kreatininde bazalden en az \%50 artış olarak tanımlanmıştır (26). 
NLO'nın normal aralığı tam olarak bilinmemekle birlikte Amerikan halkında yapılan önceki çalışmalarda ölçülen en yüksek nötrofil sayısı en düşük lenfosit sayısına bölündüğünde 4.7 değeri bulunmuştur (27). Benign hastalıklarda $(28,29)$ veya kanser cerrahisi ile ilişkili çalışmalarda $(30,31)$ inflamatuvar belirteç olarak NLO'nın değerlendirildiği çalışmaların çoğunda NLO kesme değeri $\geq 5$ olarak kullanılmıştır. Bizim çalışmamızda ise akut pankreatitte $\mathrm{ABH}$ için kesme değeri 11.24 bulunmuştur.

Çalışmamızda NLO, Ranson skoru ve BISAP skoru gibi pankreatitin şiddetini gösteren parametreler ile korele bulunmuştur. NLO'nun yüksek olması aslında BISAP veya Ranson skoru gibi pankreatitin şiddetini öngören bir tetkik olarak da düşünülebilir. Böylece NLO'nun sadece $A B H$ gelişimi için bağımsız bir öngörücü olmayabileceği ve aslında şiddetli pankreatitin de bir göstergesi olabile- ceğini düşündürmektedir. Şiddetli pankreatitli hastalarda da doğal olarak da $\mathrm{ABH}$ gelişimi daha fazla görülecektir. Bu konuda yapılacak prospektif çalışmalara ihtiyaç vardır.

Çalışmamızın bazı kısıtılıkları mevcuttur. Çalışmamız retrospektif ve tek merkezli bir çalışmadır. Hasta sayısı nispeten azdır. Hastaların çoğunda idrar miktarı verilerine ulaşılamadığı için $\mathrm{ABH}$ tanım ve evrelemesinde idrar kriterleri kullanılamamış ve sadece kan kreatinin değerlerine göre tanımlama yapılmıştır.

Sonuç olarak bazal NLO akut pankreatitte $A B H$ gelişimini predikte etmede güçlü adaylardan biri olabilir. Bu hastalarda akut böbrek hasarını öngördürmede hücresel immünite ve inflamasyon önemli rol oynamaktadır. Çalışmamız büyük katılımlı ve prospektif çalışmalarla desteklenirse bu hasta grubunda $\mathrm{ABH}$ riski yüksek olan hastaların erken tanımlanmasında faydalı bir belirteç olarak kullanılabilir.

\section{KAYNAKLAR}

1. Cho SK, Jung S, Lee KJ, Kim JW. Neutrophil to lymphocyte ratio and platelet to lymphocyte ratio can predict the severity of gallstone pancreatitis. BMC Gastroenterol 2018;18:18.

2. Almeida N, Fernandes A, Casela A. Predictors of severity and in-hospital mortality for acute pancreatitis: Is there any role for C-reactive protein determination in the first 24 hours? GE Port J Gastroenterol 2015;22:187-9.

3. Petejova N, Martinek A. Acute kidney injury following acute pancreatitis: A review. Biomed Pap Med Fac Univ Palacky Olomouc Czech Repub 2013;157:105-13.

4. Zhou J, Li Y, Tang Y, et al. Effect of acute kidney injury on mortality and hospital stay in patient with severe acute pancreatitis. Nephrology (Carlton) 2015;20:485-91.

5. Kes P, Vucicevic $Z$, Ratkovic-Gusic I, Fotivec A. Acute renal failure complicating severe acute pancreatitis. Ren Fail 1996;18:621-8.

6. Sharfuddin AA, Molitoris BA. Pathophysiology of ischemic acute kidney injury. Nat Rev Nephrol 2011;7:189-200.

7. Bonventre JV, Yang L. Cellular pathophysiology of ischemic acute kidney injury. J Clin Invest 2011;121:4210-21.

8. Bhat T, Teli S, Rijal J, et al. Neutrophil to lymphocyte ratio and cardiovascular diseases: a review. Expert Rev Cardiovasc Ther 2013;11:55-9.

9. Li Y, Zhao Y, Feng L, Guo R. Comparison of the prognostic values of inflammation markers in patients with acute pancreatitis: a retrospective cohort study. BMJ Open 2017;7:e013206.

10. Yilmaz H, Cakmak M, Inan O, et al. Can neutrophil-lymphocyte ratio be independent risk factor for predicting acute kidney injury in patients with severe sepsis? Ren Fail 2015;37:225-9.

11. Gameiro J, Agapito Fonseca J, Monteiro Dias J, et al. Prediction of acute kidney injury in cirrhotic patients: a new score combining renal, liver and inflammatory markers. Int J Nephrol Renovasc Dis 2018;11:149-54.

12. Abu Alfeilat M, Slotki I, Shavit L. Single emergency room measurement of neutrophil/lymphocyte ratio for early detection of acute kidney injury (AKI). Intern Emerg Med 2018;13:717-25.

13. Banks PA, Bollen TL, Dervenis C, et al; Acute Pancreatitis Classification Working Group. Classification of acute pancreatitis-2012: revision of the Atlanta classification and definitions by international consensus. Gut 2013;62:102-11.

14. Kellum JA, Lameire N; KDIGO AKI Guideline Work Group. Diagnosis, evaluation, and management of acute kidney injury: a KDIGO summary (Part 1). Crit Care 2013;17:204.

15. Wan L, Bagshaw SM, Langenberg C, et al. Pathophysiology of septic acute kidney injury: what do we really know? Crit Care Med 2008;36(4 Suppl):S198-203.

16. Thurman JM, Ljubanovic D, Royer PA, et al. Altered renal tubular expression of the complement inhibitor Crry permits complement activation after ischemia/reperfusion. J Clin Invest 2006;116:35768.

17. Hassoun HT, Grigoryev DN, Lie ML, et al. Ischemic acute kidney injury induces a distant organ functional and genomic response distinguishable from bilateral nephrectomy. Am J Physiol Renal Physiol 2007;293:F30-40.

18. Li L, Huang L, Sung SS, et al. NKT cell activation mediates neutrophil IFN-gamma production and renal ischemia-reperfusion injury. J Immunol 2007;178:5899-911.

19. Wu H, Chen G, Wyburn KR, et al. TLR4 activation mediates kidney ischemia/reperfusion injury. J Clin Invest 2007;117:2847-59.

20. Kelly KJ, Williams WW, Jr., Colvin RB, et al. Intercellular adhesion molecule-1-deficient mice are protected against ischemic renal injury. J Clin Invest 1996;97:1056-63.

21. Linfert $D$, Chowdhry T, Rabb H. Lymphocytes and ischemia-reperfusion injury. Transplant Rev (Orlando) 2009;23:1-10.

22. Zahorec R. Ratio of neutrophil to lymphocyte counts--rapid and simple parameter of systemic inflammation and stress in critically ill. Bratisl Lek Listy 2001;102:5-14.

23. Demols A, Le Moine O, Desalle F, et al. CD4 (+) T cells play an important role in acute experimental pancreatitis in mice. Gastroenterology 2000;118:582-90. 
24. Azab B, Jaglall N, Atallah JP, et al. Neutrophil-lymphocyte ratio as a predictor of adverse outcomes of acute pancreatitis. Pancreatology 2011;11:445-52.

25. Jeon TJ, Park JY. Clinical significance of the neutrophil-lymphocyte ratio as an early predictive marker for adverse outcomes in patients with acute pancreatitis. World J Gastroenterol 2017;23:3883-9.

26. Wang $Y$, Fuentes $H E$, Attar BM, et al. Evaluation of the prognostic value of neutrophil to lymphocyte ratio in patients with hypertriglyceridemia-induced acute pancreatitis. Pancreatology 2017;17:893-7.

27. Bain BJ. Ethnic and sex differences in the total and differential white cell count and platelet count. J Clin Pathol 1996;49:664-6.

28. Furman MI, Gore JM, Anderson FA, et al; GRACE Investigators. Elevated leukocyte count and adverse hospital events in patients with acute coronary syndromes: findings from the Global Registry of Acute Coronary Events (GRACE). Am Heart J 2004;147:42-8.
29. Gibson PH, Croal BL, Cuthbertson BH, et al. Preoperative neutrophil-lymphocyte ratio and outcome from coronary artery bypass grafting. Am Heart J 2007;154:995-1002.

30. Halazun KJ, Aldoori A, Malik HZ, et al. Elevated preoperative neu trophil to lymphocyte ratio predicts survival following hepatic resection for colorectal liver metastases. Eur J Surg Oncol 2008;34:5560.

31. Sharaiha RZ, Halazun KJ, Mirza F, et al. Elevated preoperative neutrophil:lymphocyte ratio as a predictor of postoperative disease re currence in esophageal cancer. Ann Surg Oncol 2011;18:3362-9. 